\title{
Friction generated by elastomeric ligature with and without polymer coating
}

\section{Atrito gerado por ligaduras elásticas com e sem cobertura polimérica}

\author{
Mariana M. MARTINS \\ Tatiana A. LIMA \\ Graduate student - Department of Orthodontics of Rio de Janeiro State University - Rio de Janeiro \\ - Brazil
}

\section{Andressa O. B. TEIXEIRA}

MSc - Department of Orthodontics - Rio de Janeiro State University - Rio de Janeiro - Brazil

\section{Flavia ARTESE}

PhD - Associate Professor - Department of Orthodontics of Rio de Janeiro State University - Rio de Janeiro - Brazil

\author{
Alvaro De Moraes MENDES \\ PhD - Associate Professor - Department of Orthodontics of Rio de Janeiro State University - Rio \\ de Janeiro - Brazil
}

\begin{abstract}
SUMMARY
The purpose of this study was to compare, in vitro, the friction generated by elastomeric ligature with polymer coating to conventional elastomeric ligature.

Three calipers of stainless steel wire were tested: $0.020 ", 0.019$ " $\mathrm{x} 0.025$ " and

0.019 " x 0.026 ". Two acrylic plates were manufactured. An upper central incisor bracket was fixed to one of them and a canal (or groove) - where orthodontic wires were fixed - was made on the other. The acrylic plates were adapted and adjusted to a traction test machine so that the wire would fit into the bracket slot without any angulation. Ten ligatures of each kind were tested for each wire. The wires were pulled and slid into the bracket for a distance of $5 \mathrm{~mm}$ at a constant rate of $5 \mathrm{~mm} / \mathrm{min}$. The obtained data was compared by Student's T test with the significance value of $\mathrm{p}<0.05$ and revealed the existence of great differences between the forces generated for each wire caliper. The conventional ligatures without polymer coating generated significantly higher forces than the ligatures with coating. The polymer-coated ligatures generated lower friction than the conventional ligature in all calipers evaluated. That suggests that this type of ligature should be the best choice for sliding mechanisms.
\end{abstract}

\section{UNITERMS}

Polymers; friction; orthodontics.

\section{INTRODUCTION}

The friction force clinically generated during sliding mechanisms by the ligature/bracket/wire contact tends to prevent desired orthodontic movement: however the archwire should be properly fit into the slot and well tied to the bracket in order to obtain orthodontic movement. In this way, a part of the applied force is lost due to the generated friction; therefore, the applied force should be larger to compensate this loss. It is a loss that generates problems such as anchorage loss and decrease of movement rate [1-2]. A number of factors influences friction, such as wire composition [3], arch dimension [4-6], bracket material [7], form of ligation [1] and presence of active dental inclinations and torques [8].

Currently, the procedure mostly used by orthodontists to tie the bracket to the archwire is the elastomer- 
ic ligature, because it can be placed quickly. It also reduces chair time, is comfortable, has low cost and is available in a wide variety of colors, thus motivating young people to undergo orthodontic treatment [9].

Elastomeric ligatures with a special polymer coat have recently become available in the market. The purpose of this coat is to reduce the friction surface, increase its resistance, facilitate its placement and reduce the adhesion of bacteria as described by the manufacter [10].

Thus, the purpose of the present paper is to present the work performed to evaluate one of the mentioned characteristics, by checking if these ligatures with polymer coating generate less friction in the group ligature/ bracket/ wire, when compared to conventional ligatures. There are few articles about this kind of elastomeric ligatures and the reduction of the friction force during sliding mechanics would be an option to decrease the applied force and increase the movement rate.

\section{Material And Methods}

Two acrylic plates were devised for the mechanical test in order to simulate a sliding mechanism. One of these plates contained a groove where the stainless steel wire was fit. An upper central incisor bracket was attached to the middle of the other plate. This stainless steel bracket had no angulation with a 0.022" slot (10.65.201, Morelli, Sorocaba, SP, Brazil). Both plates were adapted to and adjusted in a traction machine test (EMIC DL-500 FD, São José dos Pinhais, PR, Brazil), so that the plate with the bracket was adjusted to the fixed arm of the machine, while the other plate with the stainless steel wire was fit to the movable arm (Figure 1). The plates were parallel to each other, so that the stainless steel wire would be fit in the bracket slot without any angulation. A1 Newton load was used and the tests enabled the wire to slide in the vertical direction along the bracket for a distance of $5 \mathrm{~mm}$, at a constant rate of $0.5 \mathrm{~mm} / \mathrm{min}$ [11].

Two types of gray elastomeric ligatures were tested: ligatures with (382-020 Super Slick Ties, TP Orthodontics, Inc, La Porte, IN, USA) and without (383-020 TP Orthodontics, Inc. La Porte, IN, USA) polymeric coating with thirty samples in each group. These ligatures were evaluated with three different archwire calipers: 0.020 ", 0.019 " $\mathrm{x} 0.025$ " and 0.019 " x 0.026", also from the same manufacturer (TP Orthodontics, Inc. La Porte, IN, USA). The choice of these three different calipers of wire was due to the fact that these archwires are commonly used in sliding mechanisms.

To prevent variation in archwire size, the same 15 $\mathrm{cm}$ wire segment of each caliper was used for each ligature group. Artificial saliva was used to irrigate the group ligature/bracket/wire as simulation of intraoral environment. The artificial saliva was obtained from the University Pharmacy, UFRJ and was irrigated with a syringe in order to involve the whole of group ligature/bracket/wire.

The results were obtained with the help of Mtest software (version 1.01, EMIC-Equipment and Systems Testing Ltd, São José dos Pinhais, PR, Brazil.) and were presented as means and standard deviations. The independent Student's T test was used to evaluate differences between groups with and without polymeric coating. Significance value was established at $\mathrm{p}<0.05$.

\section{Results}

The results found from the mechanic sliding simulation showed that the ligatures without polymeric coating generated higher averages forces than ligatures with coating in all archwires calipers evaluated (Table 1). The largest reduction was at 0.019 " $\mathrm{x} 0.026$ " caliper (rectangular wire with rounded corner) with $45.7 \%$, and respectively by the 0.019 " $\mathrm{x} 0.025$ " wire (rectangular wire with alive corner) and the 0.020 " wire (round wire) with $30.2 \%$ and $20.1 \%$ reduction.

Table 1 - Descriptive and statistical analysis OF FRICTION TEST

\begin{tabular}{|c|c|c|c|c|c|c|c|c|c|}
\hline & \multicolumn{3}{|c|}{$0.020 "$} & \multicolumn{3}{|c|}{$0.019 " \times 0.025 ”$} & \multicolumn{3}{|c|}{$0.019 "$ X 0.026" } \\
\hline & Mean $(\mathrm{N})$ & $\begin{array}{l}\text { S. Devia- } \\
\text { tion }\end{array}$ & p-Value* & Mean (N) & $\begin{array}{l}\text { S. Devia- } \\
\text { tion }\end{array}$ & p-Value* & Mean (N) & S. Deviation & p-Value* \\
\hline $\begin{array}{l}\text { WITH } \\
\text { COVERING }\end{array}$ & 0.8400 & 0.12481 & \multirow{2}{*}{0.003} & 1.1920 & 0.18177 & \multirow{2}{*}{$<0.001$} & 0.3180 & 0.12891 & \multirow{2}{*}{0.002} \\
\hline $\begin{array}{l}\text { WITHOUT } \\
\text { COVERING }\end{array}$ & 1.0610 & 0.1052 & & 1.7080 & 0.20220 & & 0.5860 & 0.19219 & \\
\hline
\end{tabular}

Note: * Independent Student's T test. Significance value: $\mathrm{p}<0.05$. 


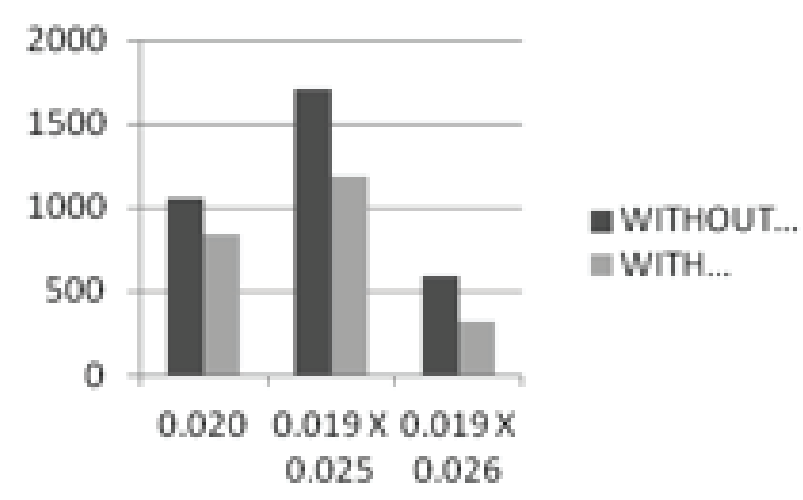

\section{Discussion}

The polymer coated ligatures have been suggested to reduce the friction and this study agrees with this suggestion by showing that the polymer coating may influence the decrease of the friction generated by the sliding mechanics.

The laboratory research was meant to isolate and eliminate most of the possible variables that involve the friction generated in the sliding mechanics and focused only on the difference in the treatment of surface of elastomeric ligatures with and without polymer coating. It found significant reduction of force generated in all calipers evaluated. In that manner, the plates were parallel to each other, so that the archwire would be fit into the slot bracket without any angle, as already observed in other studies[12]. Other studies used some angulations in the wire to simulate side effects of sliding mechanics; however the friction caused by these angulations could influence the results of the polymeric coat [12-15]. Some studies have demonstrated that there are no significant differences between wet and dry conditions. Because of diverging results regarding the use artificial saliva, we measured friction in the wet state with the purpose of simulating oral environment [1].

All ligatures with polymer coating presented smaller forces during the mechanical test (Table 1), in accordance to Hain et al. work [1] that evaluated the effects of the ligation methods in the friction generated by this type mechanics. These authors found a reduction of up to $60 \%$ when comparing the coated ligatures with the non-coated ligatures and they emphasized that the reduction was more significant when the ligatures were tested with lubricated saliva. The reduction found in our research was lower but statistically significant (Table 1) and the highest decrease of friction occurred with the 0.019 " x 0.026 " archwire (45.7\%).

Chimenti et all. [16] also evaluated the friction force generated by ligatures with and without coating and found a significant reduction of force generated by the ligatures with covering, with a variation of $23 \%$ to $43 \%$ of reduction; however the study was accomplished in a dry condition. However, these values were more similar when compared to our results with a variation of $20.1 \%$ to $45.7 \%$.

These comparisons should be carefully analyzed because even though similar methods were used, they were not identical. The amount of play of wire inside the slot; the type of surface finishing, different trademarks and different types and bracket sizes employed in different researches have also been mentioned in the literature as possible confusing factors in the interpretation of the results [1].

\section{Conclusion}

The polymer-coated ligatures generated forces significantly lower than the conventional ligature in all wire calipers evaluated. That suggests that this type of ligatures may be more appropriate for sliding mechanics.
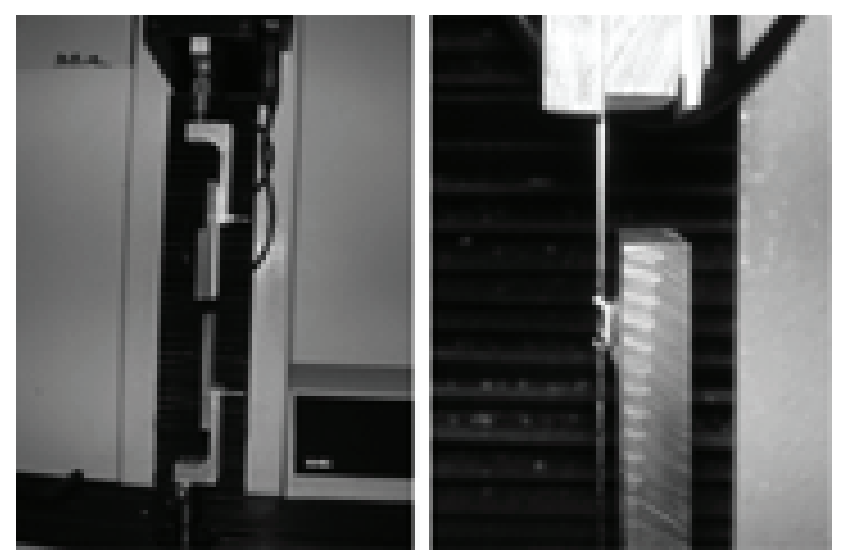

Figure 1 - Plates with the bracket adjusted to the fixed arm of the machine (EMIC)

\footnotetext{
Resumo

O objetivo deste estudo foi comparar, in vitro, o atrito gerado por ligaduras elásticas com cobertura polimérica com ligaduras convencionais. Três calibres de fio de aço inoxidável foram testados: 0.020 ", 0.019 ” x 0.025 " and 0.019 " x 0.026

". Foram confeccionadas duas placas de acrílico, onde em uma placa foi colado um bráquete de incisivo central superior e na outra placa foi feita uma canaleta onde os fios ortodônticos foram fixados. As placas de acrílico foram adaptadas e reguladas em uma máquina de ensaio de tração de maneira que o fio se encaixasse no bráquete sem nenhuma angulação.
} 
Para cada fio foram testadas 10 ligaduras de cada tipo. Os fios foram tracionados, deslizando pelo slot do bráquete a uma distância de $5 \mathrm{~mm}$ com uma velocidade constante de $5 \mathrm{~mm} / \mathrm{min}$. Os resultados obtidos foram comparados pelo teste $t$ de Student com significância de $\mathrm{p}<0.05$, e revelaram a existência de diferenças significativas entre as forças geradas para cada calibre de fio. As ligaduras convencionais sem cobertura polimérica geraram forças significativamente maiores que as ligaduras com cobertura polimérica. As ligaduras com cobertura polimérica geraram menor atrito que as ligaduras convencionais em todos os calibres de fio avaliados, sugerindo que estas ligaduras devem ser o material de escolha nas mecânicas de deslizamento.

\section{UNITERMOS}

Elastômeros; fricção; Ortodontia

\section{REFERENCES}

1. Hain M; Dhopatkar, A; Rock, P. The effect of ligation method on friction in sliding mechanics. Am. J. Orthod. Dentofacial Orthop. 2003;123(4):416-422.

2. Drescher D, Bourauel C, Schumacher HA. Frictional forces between bracket and arch wire. Am J Orthod Dentofacial Orthop. 1989; 96:397-404

3. Kusy RP; Whitley JQ. Coefficients of friction for arch wires in stainless steel and polycrystalline alumina bracket slots. I. The dry state. Am. J. Orthod. Dentofacial Orthop. 1990;98:300-312.

4. Frank CA, Nikolai RJ. A comparative study of friction resistance between orthodontic bracket and arch wire. Am. J. Orthod. Dentofacial Orthop 1980;78:593-609.

5. Peterson L, Spencer R, Andreassen GA. Comparison of friction resistance for Nitinol and stainless steel wire in edgewise brackets. Quintessence Int. 1982;13:563-571.

6. Huffman D, Way DC. A clinical evaluation of tooth movement along archwires of two different sizes. Am J Orthod. Dentofacial Orthop 1983; 83:453-459.

7. Keith O, Jones SP, Davies EH. The influence of bracket material, ligation force and wear on friction resistance of orthodontics brackets. Br J Orthod. 1993;20:109-115.

8. Tidy DC. Frictional forces in fixed appliances. Am. J. Orthod. Dentofacial Orthop. 1989;96:249-254.

9. Taloumis, J. L. et al. Force decay and deformation of orthodontic elastomeric ligatures. Am. J. Orthod. Dentofacial Orthop. 1997;111(1):1-11.

10. Devanathan, D. Performance study of a low friction ligature. White paper from research laboratories of TP Orthodontics, Inc, LaPorte, Indiana. 2000.

11. Thomas S, Sherriff M, Birnie D. A comparative in vitru study of the frictional characteristics of two types of self-ligating brackets and two types of pre-adjusted edgewise brackets tied with elastomeric ligatures. Eur J Orthod.1998;20:589-596.

12. Baker KL, Nieberg LG, Weimer AD, Hanna M. Frictional changes in force values caused by saliva substitution. Am. J. Orthod. Dentofacial Orthop. 1987;91:316-320.

13. Ireland AJ, Sheriff M, Mc Donald F. Effect of bracket and wire composition on frictional forces. Eur J Orthod.1991;13:322-328.

14. Riley JL, Garrett SG, Moon PC. Frictional forces of ligated plastic and metal edgewise brackets. J. Dent. Res. 1979; 58:A21

15. David J. De Franco, Robert E. Spiller, and J. A. von Fraunhofer.: Frictional resistances using Teflon-coated ligatures with various bracket-archwire combinations. Angle Orthod. 1995; 65:63-72.
16. Chimenti C, Franchi L, Di Giuseppe MG, Lucci M. 2005: Friction of Orthodontic Elastomeric Ligatures with Different Dimensions. Angle Orthod. 2005;75(3):421-425.

Recebido: $12 / 05 / 2011$ Aceito: 06/09/2011

Corresponding author: Dr. Alvaro de Moraes Mendes,

Address: Boulevard 28 de Setembro 157 sala 230, Vila Isabel, Rio de Janeiro - RJ, Brazil, Zip Code: 20551-030,

Telephone: (55) 21 2569-3829 e-mail: tatiorto@gmail.com 